\title{
What is a Significant Educational Experience?
}

\section{GEOFFREY HINCHLIFFE}

\begin{abstract}
This article analyses the nature of an educational experience by taking as its starting point Dewey's Art as Experience in order to identify what it is that counts as a significant or worthwhile experience. Dewey suggests that an experience needs to have an integral character in which the different phases of the experience are related and which tends towards a conclusion. Furthermore, an experience also needs to have the character of what Dewey calls an 'undergoing', an engagement with content which may be difficult or painful. It is suggested that this kind of experience may be seen in terms of a 'light' pedagogy in which content is allowed to unfold. This is contrasted with educational experiences that are 'teacher-driven' or 'learner-driven'.
\end{abstract}

Education is often analysed in terms of process or outcomes. But in this article I wish to focus on the experience of education from the standpoint of the child or student who is having the experience. I want to see if there are characteristics of this experience that can be identified in such a way that we can say, with reasonable confidence, that the experience was worthwhile. In particular, I am keen to analyse this experience independent of results and outcomes, or, in a word, independent of assessment. This may seem nonsensical to all of those who assume that formal learning cannot really happen at all unless assessment is built into the process of learning, but here I want to put this assumption to one side and just concentrate on the experience itself. ${ }^{1}$ For even if no assessment has taken place at all, something has happened nonetheless: an experience has occurred and the child may even be able to communicate something of the nature of that experience later on. It may, of course, not be a particularly memorable or pleasing experience, but something has happened all the same.

As the article develops I shall try and develop a more philosophical understanding of what I mean by a significant experience. But for the time being a few non-philosophical remarks are in order just to fix the starting point. First, I am referring to a significant or worthwhile experience and not just any old experience. For example, one may derive great pleasure from reading a piece by, say, a parliamentary sketch writer; but the pleasure does not usually extend for long after one has finished; whereas a 
significant experience is one that can be set in the context of life-activities. Of course there are many degrees of significance and only a few, if any, experiences will turn out to be, of themselves, life transforming. More often than not a significant experience takes its place in the context of activities or practices in which one is engaged and so only affects a part of one's life. Moreover, a significant experience does not need to be remembered over a lifetime: its lessons can be absorbed and brought to bear on subsequent experiences so though it may be forgotten it may still possess efficacy.

All this implies that a significant educational experience is one such that, I suggest, if it is taken outside its educational context, may be compared to other, non-educational experiences. So a good seminar in philosophy may be a significant experience in the sense that the long walk I had last weekend in which I started to notice certain types of birdsong for the first time was a significant experience; or the lengthy conversation I had in the pub last night that turned out to be significant because it disabused me of a prejudice that had started to form in me, hitherto unnoticed. Of course, most (not all) experiences occur in context so I am far from asserting that the worthwhile experience is entirely discrete and context-free. Indeed, without the context, interpretation of the experience may be virtually meaningless. Nevertheless, we do sometimes consider different experiences and compare them, despite the fact they each come with different contexts, and a significant educational experience, I am suggesting, could be included in this in this kind of informal exercise.

As I have already hinted, an educational experience need not be significant. It may turn out to have been a very poor one indeed and best forgotten. Thus dissatisfaction at school is typically characterised by children in terms of a succession of poor or indifferent experiences, from their point of view. It may even turn out that although children did indeed have a memorable experience it had nothing to do with what the teacher and school had aimed and planned for. In this case, what was undergone was not so much an indifferent experience but a completely different one from that intended by the teacher. Whether it was an educational experience is another question. But it may have been worthwhile and significant all the same. ${ }^{2}$

If we suppose, along with R. S. Peters, that the term 'educational' implies that 'something worthwhile has been transmitted' (or perhaps developed) which involves knowledge and understanding (see Peters, 1966, pp. 25 and 30), this does not, in itself, imply that the process of being educated as such has been composed of worthwhile experiences from the standpoint of the person undergoing that process. It may well be that both at the time, and also on subsequent reflection, one realises that very few of one's educational experiences have been worthwhile. ${ }^{3} \mathrm{~A}$ significant educational experience in the sense I wish to explore is one that helps to make education as a worthwhile process actually feel worthwhile as experienced by the child or student.

I am assuming that an educational experience is one that has an identifiable beginning and an end and qualifies as a single experience 
under some appropriate description. For example, a course, unless it is a very short, is composed of a number of related experiences but it is always possible to view the whole course as 'an experience'. There is an understandable tendency to make educational experiences fairly short and sharp (this greatly assists assessment) but many significant experiences may last days or weeks (as readers of Bleak House will testify). There are, then, no fixed rules as to how long an experience can last but it must have some kind of identifiable end point. In practice, of course, the duration of educational experiences is not only determined by subject matter but by timetabling constraints and the like.

I will first of all briefly set out two fairly common types of educational experience: this will more firmly locate the terrain I wish to explore. The rest of this article will then be spent elaborating the particular type of experience with which I am concerned.

\section{TWO TYPES OF EDUCATIONAL EXPERIENCE}

The first example is taken from the DfES Key Stage 3 National Strategy document, Pedagogy and Practice (2004). Here I focus on Unit 2: Teaching Models. If we look at what is termed the 'deductive teaching model' (p. 11) we learn that this is concerned with the teaching of concepts and specifically with the attributes that a concept possesses, which must be understood if it is to be distinguished from other, related concepts. The example given concerns democracy: "with a concept of democracy in a citizenship lesson, the concept rule might be that "Democracy is government of the people by the people", The document then outlines for teachers the steps by which these concept rules may be taught, as follows:

The deductive teaching model has five phases which can be divided into episodes.

- The teacher begins the lesson with the concept rule, or a statement of what the pupils will attempt to prove during the lesson.

- The teacher provides some examples which show proof of the concept rule.

- The teacher, through questioning of the pupils, identifies the critical attributes and the non-critical attributes which are essential and nonessential characteristics of the concept.

- The teacher follows this by showing examples and non-examples of the same concept to the pupils.

- The pupils must categorise the examples or non-examples (those which do not show essential characteristics of the concept rule) by explaining why they do or do not fit the concept rule being discussed (DfES, 2004, Teaching Models, Unit 2, p. 11).

Now, in many ways it is difficult to quarrel too much with this approach. It is systematic and purposeful. The process is allied to the objectives of the lesson. It is interactive and space is given for student activity. Yet 
despite all these merits, not least of which is that there is a sporting chance that the concept rule will be understood, we might feel a certain unease. For one thing, the entire process is directed-indeed, controlled-by the teacher. There seems little room for a student voice which has not already been sanctioned within the process. There also seems little chance of exploring the concept in such a way that relates to student or child experience (though much depends here on the kind of examples used). There is little or no chance of what might be termed 'creative deviancy'-note that the 'pupils must categorise the examples by explaining why they do or do not fit'. The lesson seems to read as a series of tasks to be accomplished. To be sure, the tasks are thought through and relate to the objectives but it is not clear that there is any space here for any enjoyment or fun: there seems little opportunity to relax in this lesson. Right from the start, the teacher has an agenda to drive through — and everyone must play their part.

Now, I do not deny for one moment that such a lesson could turn out to be enjoyable: much here would depend on the teacher style, the rapport she has with the class and the richness of the examples discussed. Nevertheless, from the standpoint of the children, this experience is essentially teacher-driven. I would also say, in parenthesis, that if a teacher taught like this for each lesson every day he or she would probably end up completely exhausted before the end of the school week.

For the second type of educational experience, I take as my example The Art of Constructivist Teaching in the Primary School by Nick Selley (1999). Here we are told, in no uncertain terms that, in contrast to orthodox transmission pedagogies, the constructivist approach allows that 'the learner always controls the sense she makes of an experience'. However, what may seem to be a highly questionable epistemological stance (namely rampant subjectivism) is modified through the additional requirement that constructions and interpretations be validated: '. . y you are helping the child to build up the best version of his/her model and to test it against experience' (1999, p. 24). This is achieved through conversation, questioning and investigation. However, as Selley himself concedes, the business of 'trying out one's own ideas' is not easy: scientific investigation, for example, requires that the student 'must know what the question is, must want to find a solution, must know a promising line of procedure, must know how to set up and manipulate the necessary apparatus and must expect to be allowed to extract meaning from the results'. And presumably, the more any of this is lacking the greater the teacher intervention is required. Constructivism seems to place a considerable burden and responsibility on the child. What one might term a child- or student-driven educational experience is not so much the having of an experience but the directing and managing of it. This looks difficult, by any standards, because it seems to involve not only an activity but also the meta-activity by the child of monitoring, recording and communicating what is going on in the primary activity.

So, for example, in the constructivist teaching of history, the child must be able to demonstrate the construction or interpretation of evidence through 'a talk, a diagram, role play or a drawing ... by examining this 
representation we are able to assess the validity or fairness of the construction regarding the available visible evidence of the past' (Copeland, 1998, p. 125). What concerns me here is not so much that these constructions may not be historically accurate: after all the historical understanding of the child is bound to be simplified or abbreviated and any serious misconceptions can always be corrected. It is that so much is expected of the child: just as the teacher ends up exhausted after intense teacher-driven learning, so it seems to me that children will end up burntout before the end of the week if they are subjected to a series of non-stop constructivist exercises across the curriculum.

Nevertheless, both these types of educational experience seem to me to have their place in any pedagogy. There will be times when a teacherdriven approach is called for: for example, if it is felt that certain basic concepts have to be understood before any further progress can be made. There will be other times when a more constructivist approach seems appropriate because this gives the child the space and time to design and construct their own learning in their own way and at their own pace. But I now wish to explore a different type of experience which is neither teacher nor child nor learner-driven.

\section{DEWEY'S CONCEPT OF AN EXPERIENCE}

Instead of turning to John Dewey's works on education, I wish to examine his concept of aesthetic experience. He did not write on this systematically until the early 1930s when he was in his seventies. His working assumption is that aesthetic experiences are not special events that only happen to certain highly sensitive individuals in particular circumstances, but are much more widespread. This assumption is made good by the analysis of experience that he provides in Art as Experience (1934). He is concerned, initially, in this important book, to distinguish those experiences with little connection with each other and which prompt opposing emotions and reflections from what he calls 'an experience'. Here, he says, 'the material experienced runs its course to fulfilment' (Dewy, 1934, p. 35) and only then is it identified and integrated within the general stream of experience. He puts this point more cogently as follows: 'Such an experience is a whole and carries with it its own individualising quality and self-sufficiency. It is an experience' (p. 35). Dewey's concern, then, is to try and say how we have an aesthetic experience by pointing out that although there may be a succession of events or experiences nevertheless there is a unity whilst at the same time the self-identity of each part is maintained. There is a 'flow', the sense of which he tries to capture through the word 'phases', and he contrasts this with Locke and Hume's analysis of experience in terms of impressions and ideas which are discrete and separate. The idea of 'phases' is that an experience may be composed of emotions, thoughts and activities which have a connection and continuity (though that connection may itself need to be explored and unfolded). This flow culminates in a consummation of a movement-a 
conclusion-which implies that the full meaning of an experience can only be grasped if the experience has also been undergone in all its phases. Dewey goes on to say that a quality pervades the experience which he characterises in terms of a property: "we may find that one property rather than another was sufficiently dominant so that it characterises the experience as a whole' (p. 37).

We can, I think, readily recognise this description as one that approximates to experiencing a work of art. Thus, we might say that Guernica conveys a certain quality of experience which is quite different from, say, Monet's different versions of Water Lilies, painted when he lived at Giverny. However, Dewey wishes to extend this thought to claiming that, for example, thinking has a certain aesthetic quality when it takes the form of a movement of an idea, a 'movement of anticipation and cumulation, one that finally comes to completion ... and has a satisfying emotional quality because it possesses internal integration and fulfilment reached through ordered and organised movement' (p. 38). With 'an' experience it is the whole process that is experienced and not just the outcome. Thus moral actions need not be experienced solely on the plane of duty but may also have an aesthetic character when they have a unity reaching a conclusion. Dewey maintains that the enemies of the aesthetic are neither the practical nor the intellectual, but the "humdrum ... and submission to convention ... both coerced submission and slackness of loose ends are deviations in opposite directions from the unity of an experience' (p. 40). He is suggesting, then, that the aesthetic is an integral experience and that this type of experience is by no means confined to the conventionally aesthetic.

Dewey goes on to identify further elements that characterise this integral experience. First, he states that struggle and conflict may be enjoyed as a feature of developing an experience: it is not necessary for the experience to be passive, as when one surveys works of art in a museum. He develops this idea further by suggesting that for any integral experience there is an element of 'undergoing', of suffering even: this ensues because an experience involves taking in something and may be 'more than placing something on the top of consciousness over what was previously known. It involves reconstruction which may be painful' (p. 41). An integral experience therefore requires an engagement with materials, ideas or processes and cannot be unduly hurried because there is a time appropriate to its unfolding. It cannot be cut up or divided into small parts or 'chunks' without compromising its unity. It cannot be appropriated, directed or managed without the risk of directly undermining the very quality that constitutes the experience's particular value. Whether this appropriation be by somebody else (e.g. a teacher) or oneself (in the capacity of someone keen to manage their own learning) something of the experience may be lost because it has not been properly 'undergone'. There is a balance to be struck between doing and undergoing, a balance too often neglected in favour of doing:

Zeal for doing, lust for action, leaves many a person, especially in this hurried and impatient human environment in which we live, with 
experience of an almost incredible paucity, all on the surface. No one experience has a chance to complete itself because something else is entered upon so speedily. What is called experience becomes so dispersed and miscellaneous as hardly to deserve the name. Resistance is treated as an obstruction to be beaten down, not as an invitation to reflection. An individual comes to seek, unconsciously even more than by deliberate choice, situations in which he can do the most things in the shortest time (Dewey, 1934, p. 45).

We are only too familiar with this lament. Perhaps what Dewey could have never appreciated back in 1934 is the way that experiences today may also contain a complete absence of 'doing' to the point where experience is one of sheer passivity, hours on end, evening after evening. Although maybe if we have spent much of the day lusting for action, this is only to be expected.

Hans-Georg Gadamer's thoughts on the nature of experience (Erlebnis) are uncannily similar to those of Dewey, to the point where almost the same expressions are being used to convey meaning. Gadamer (1975/ 1989) commences his analysis with a historical overview of the meaning of Erlebnis, concluding that in Enlightenment Germany the word conveyed three senses at once: immediacy of experience, the idea that an experience makes a particular impression that gives lasting importance and that it does this through achieving a permanence that emerges out of the transiency of experience. Out of this romantic critique of rationalism emerged, according to Gadamer, a concept of experience which Dilthey employed in order to capture 'the special nature of the given in the human sciences' (Gadamer, 1975/1989, p. 65). But these units of experience are now philosophically transformed so that they become units of meaning which are intentional:

If something is called or considered an Erlebnis, that means it is rounded into the unity of a significant whole ... an experience is no longer just something that flows past quickly in the stream of conscious life; it is meant as a unity and thus attains a new mode of being one (p. 66).

And a little later, Gadamer alludes to the idea of an experience as an adventure (in contrast with episodes which are a 'succession of details which have no inner coherence and for that reason have no permanent significance' [p. 69]) which must be 'undergone like a test or a trial from which one emerges more enriched, more mature'. Gadamer goes on to suggest that such an experience is taken out of the continuity of life and related to the 'whole of one's life'. For on the one hand there is the 'experiencing' in its immediacy and vitality but there is also the experience once it has been integrated into one's life so that its significance may go beyond the meaning it had whilst it was in the process of being undergone.

Thus Gadamer adds something to Dewey's account. First of all, he stresses that an experience is fused with the experience of life itself and so 
the meaning of a single experience is never completely exhausted through conceptual determination: the meaning of an experience may always be revised at some point. Gadamer suggests that some experiences are not only not easily forgotten but also that they may take some time to assimilate, with the implication that this assimilation may never be complete even if one thinks it is. Second, having an experience-once we think of it as a kind of adventure — can be a risky business: it takes us out into the uncertain. But these observations are, I think, implicit in Dewey's account: the very fact that we undergo an experience suggests that it is something that is never completely under our control.

\section{THE NATURE OF AN EDUCATIONAL EXPERIENCE}

I now wish to further explore the nature of the kind of educational experience that Dewey's reflections on aesthetic experience allows us to identify. In the following section I will make some brief remarks on pedagogy and in the final section I will pick up Gadamer's thoughts on how educational experience can be related to one's 'whole life'.

There are many different types of educational experience but rather than enumerate some kind of discipline-based taxonomy I will look to see what three philosophers suggest: Wittgenstein, Grice and Oakeshott.

As Andrea English has recently pointed out, a central feature of learning is, or ought to be, its transformative quality (English, 2009). But how does this work? One way of approaching this problem is through Wittgenstein's discussion of 'seeing-as' in Philosophical Investigations. He supposes that:

I may contemplate a face, and then suddenly notice its likeness to another. I see that it has not changed; and yet I see it differently. I call this experience 'noticing an aspect' (1958, IIxi, p. 212).

A little later (p. 213) he distinguishes 'continuous seeing' from the 'dawning' of an aspect. Wittgenstein's point is that we are not given raw material that we then somehow interpret and derive a meaning: rather the perceptual grasp is also an interpretive one too-hence the aptness of the example of the duck-rabbit where what is seen (the perceptual data) does not change. It is also clear from his analysis that the duck-rabbit is for him a fairly primitive example, for an aspect may dawn where states of affairs are more complex: "what I perceive in the dawning of an aspect is not a property of the object, but an internal relation between it and other objects' (p. 212).

I want to suggest that one of the ways in which learning transforms is just this: the dawning of an aspect. I have in mind times when an inchoate jumble of information starts to make sense as an 'aspect' dawns on us; or perhaps the same information was seen in terms of $a, b, c$ but is now seen in terms of $x, y, z$. It might be objected that aspect-dawning is a part of learning but only a small part: in particular what Wittgenstein describes are situations where a person is simply looking and pondering. Yet when a 
teacher does step out of a teacher-driven pedagogy and lets learning happen maybe aspect-dawning is exactly what needs to take place. But for aspects to dawn there are 3 preconditions: first, there needs to be enough time, with breaks for chatting if needs be. Second, the pace mustn't be forced at the same tempo; intensive activity needs to be followed by slow reflection. And third, the subject under consideration must be selfcontained - a poem, a problem, a short text—so that in the time available it becomes possible for the learning to make sense. Aspects don't dawn by trying too hard or by trying to do too much.

Interestingly, Wittgenstein is aware that aspect-dawning may require 'someone capable of making certain applications ... quite freely. The substratum of this experience is the mastery of a technique' (p. 208) and he goes on to surmise that here we have a 'different though related concept' to that of visual aspect-dawning. And here, I want to suggest that skills are brought to fruition precisely at the point where they enable a new aspect to dawn. For example, students learning to think philosophically may start to see how concepts are linked: their tutor may tell them many times how rationality and freedom are linked in Kant but it may take the explorations of personal or situated case studies for students to realise this.

For the second type of experience I turn to an argument by Paul Grice, sometimes called the 'communication-intention' theory of meaning. However, my interest is more in the concept of recognition:

$A$ must intend to induce by $x$ a belief in an audience, and he must also intend his utterance to be recognised as so intended. But these intentions are not independent; the recognition is intended by $A$ to play its part in inducing the belief, and if it does not do so something will have gone wrong with the fulfilment of $A$ 's intentions (Grice, 1957, pp. 383-4).

Something like Grice's theory of communication-intention is needed to underpin what can happen between tutor and student in terms of a dialectic of recognition. What is particularly important is that the recognition take the form of an understanding: it is not the mere perlocutionary effect of a discourse instrumentally designed and fashioned to achieve certain outcomes. Still less is it a type of behaviour that works in the stimulusresponse mode which would not be action at all.

In what might be called normal teaching, the teacher may give instructions or give explanations in which the meaning of terms used is not an issue: the teacher is not attempting to induce any new or different beliefs from what she may standardly expect in a given situation. But there may be times of 'transformative' teaching in which the teacher is trying to induce a belief precisely by intending this to be recognised by the child or student. An example is where the teacher is trying to elicit different modes of behaviour on the part of the child in terms of interaction with other children. Or a university lecturer has reached a decisive point in an argument in which an example is used to help induce new beliefs. What is happening in both cases is that an experience is being created through the dialectic of recognition which depends not only on the teacher's intentions 
being recognised but also by the way in which the teacher intends this recognition to take place. And this discourse may be accompanied by a range of non-visual signs all of which have an illocutionary effect. Grice's theory of meaning, then, helps us to identify a non-strategic method of teaching which we could refer to as the 'communication-intention' style of teaching. And through style and context an experience is created which has all the more power for being shared by teacher and child alike.

My third example of educational experience is taken from Michael Oakeshott in his discussion of human agency in his book On Human Conduct. One mode of agency he terms 'self-disclosure' and it arises in the pursuit of aims, purposes and outcomes. Oakeshott describes it as follows:

Self-disclosure is in transactions with others and it is a hazardous adventure; it is immersed in contingency, it is interminable, and it is liable to frustration, disappointment and defeat ... an agent's choice is a response to an understood contingent situation and is therefore infected with contingency, and becoming a performance it falls into the hands of other optative agents who may defeat it and will certainly compromise it. And even if what survives bears some relation to the meaning of the act, it may disappoint and it will certainly reveal itself as but another situation to be diagnosed and responded to (Oakeshott, 1975, p. 73).

My thought here is that of the classroom or seminar room as a scene of self-disclosure in terms of the risks taken in exposing one's beliefs for public scrutiny. A few years ago in an adult education class in philosophy I was attempting to 'induce' in students certain beliefs about Kierkegaardian despair. The problem was not the despair-they all recognised angst when they saw it. The problem was understanding the idea of despair before God for persons of a secular, or at least semi-secular disposition. Our perplexity was only broached when we started to talk about the idea of surrendering yourself before God-what could this mean? One student then recounted his conversations with alcoholics in an AA group and the idea that when you reach rock bottom you admit defeat and surrender yourself, as the first stage of your recovery. Though these different kinds of self-disclosure-the person who revealed his close contact with alcoholics, those who insisted on maintaining their secularity, others who were half-baked and even one or two who, in the end, professed their Christianity - we were able to reach a better understanding of Kierkegaard. Those students risked revealing something about themselves as part of the process of learning about a particular concept of despair.

As I have mentioned, there can be no taxonomy of educational experience and the examples of aspect-dawning, recognition and selfdisclosure are far from exhaustive. An educational experience often occurs in company with others but this is by no means necessary. Moreover, teachers may not even always be aware that any experience of educational significance has happened at all, at least at the time. They may have arisen 
through the normal interaction of the seminar or classroom without having been planned.

\section{A PEDAGOGY OF EDUCATIONAL EXPERIENCE?}

I now wish to address briefly the question as to how teachers can bring about an educational experience, assuming that readers so far acknowledge their value. Can these experiences be brought about through a systematic pedagogy?

Some of the ideas discussed here have been considered by Nigel Tubbs in his 'Philosophy of the Teacher' (2005), especially in the section entitled 'The Spiritual Teacher'. For example, it would seem that closely aligned to Dewey's idea of 'undergoing' is the idea of attentiveness put forward by Simone Weil, discussed by Tubbs. Weil says:

Attention consists of suspending our thought, leaving it detached, empty and ready to be penetrated by the object ... our thought should be empty, waiting, not seeking anything but ready to receive in its naked truth the object which is ready to penetrate it (Weil, 1977, p. 56).

It is impossible not to be moved by Weil's plea for attentiveness especially in the way she couples this with the need for the effacement of the ego if learning is to have a lasting place. Yet we also should be aware that for Weil attentiveness is a means through which we can establish a closer relation with God through prayer. The subject matter itself, she insists, is of no account: learning through close attention is how we prepare ourselves for prayer. And although I am very far indeed from disparaging Weil's broader aim it is not the one being put forward here. Certainly an 'undergoing' implies that the teacher encourages attentiveness but the purpose of this is to promote educational experience through an encounter with content, and not the value of attentiveness for its own sake.

A similar thought is prompted by Tubbs' discussion of Heidegger, especially the well-known passage in 'What Calls for Thinking?'. There, Heidegger suggests that 'the proper teacher lets nothing else be learned than learning' (Heidegger, 1977, p. 356). But in the paragraph straight after the one where he discusses learning, Heidegger reverts to his central theme, that of thinking — 'we are trying to learn thinking' — and finishes his paper by re-iterating that thinking is 'our essential destiny', so that what calls for thinking 'appropriates us to thought'. But again, whatever the merits of the primacy given to thinking by Heidegger, that is not my theme in the exploration of educational experience. Far from wishing to efface the self of the learner in the face of either God or philosophy, I am exploring ways in which the experience of the self can be enriched through engagement with educational content, much of which will not include philosophy. And as my examples have made clear, I hope, a significant educational experience need not exclude the teacher. 'Letting learning happen' need not imply that learning is an isolated activity and for that reason alone (for most young people) joyless. 
Between teacher-driven learning and standing back to 'let learning happen' is a difficult position to be in. What we need is not 'no' pedagogy but a lot less of it - a 'poor pedagogy', perhaps. This idea has been suggested by Jan Masschelein who takes up Walter Benjamin's suggestion of learning as 'walking', the idea being that the student (and this could include any one who counts themselves a student of learning) opens themselves to what is around them:

The point about walking is not that it would offer us a 'better' view ... a more complete view ... but that it offers us a look that transforms whilst its evidence commands us (Masschelein, 2010, p. 45).

He goes on to commend pedagogies that do not put the student under surveillance and do not monitor (p. 50). Something like a poor pedagogy is needed to bring about educational experiences that are worthwhile. Pedagogies rich in method and outcomes may detract from the quality of the experience, which is why I cannot offer a set of methods and procedures in order to bring about richer experience. It depends on responding to the content of what is taught through establishing relations with children and students in which, in a background of trust, selfdisclosure and recognition are more likely to occur.

The metaphor of walking explored by Masschelein may start to open up what counts as an educational experience. I have in mind here the many experiences that one may have at school:

When we say that learning is not the only purpose of schooling, we do not have to invent activities demonstrably devoid of learning and show they are somehow valuable. All we have to do is to point to activities that we think are worthwhile and that we would continue to promote even if we could not state what children are learning from them. In my first year of teaching, I helped my students put on a Christmas play, supervised their operation of a school newspaper, read my favourite stories to them, advised them as they organised socials ... they enjoyed what they were doing, shared their knowledge, expressed themselves ... and in general grew as competent, caring lovable people (Noddings, 1993, p. 735).

Noddings goes on to make a broader point that excellence can take many forms and there is no point in compelling children and students to undertake subjects for which they have no liking or aptitude. Those of a 'mechanical' bent, for example, 'would follow programs in which these interests would be allowed full play ... its students could invent, construct, repair and maintain machinery ... the list is endless' (p. 740). Noddings can be interpreted as saying that a school environment can provide a wide range of valuable experiences. In my terms, these experiences will often be of an integral variety-they will have a unity, there will be a sense of 'undergoing' and the experience may have a greater significance than the bare experiencing once it is integrated, through reflection, into a self-narrative. 
I have drawn on Dewey's concept of aesthetic experience in order to elaborate what amounts to a significant educational experience, namely one that is worthwhile. Dewey has helped us to identify what might be called its formal characteristics - that the experience is integral and has a unity and is experienced as an undergoing. In addition to Dewey, Gadamer has helped us to see that what is experienced is at the level of meaning (although part of what is 'undergone' may involve tactile or auditory experience). This kind of experience may be actualised in many different ways, although I suspect that the three examples I have given in the previous section may be representative. First, the idea of an aspect dawning — when material is grasped as such and such — may be a solitary experience for which classroom activity was preparatory. So I am not suggesting that teachers need to go around seeing to it that aspects dawn. Indeed, too much organisation of material on the part of the teacher may prevent any real experience of aspect-dawning at all and actually deprive the pupil of the pleasure of seeing an aspect actually dawn on one. In the second example, the idea of recognition clearly does rely on interaction. But note that this interaction is not the mere recognition of an instruction or an order: it is the intentional grasp of material that is shared between teacher and pupil and the implicit recognition by the teacher of the pupil's having grasped it and, at the same time, the understanding by the pupil that the teacher knows that he (the pupil) has grasped it. It is one of those Eureka moments. They can often come about when a pupil or student manages to make a connection or link with material that is clearly related but has not been explicitly mentioned thus far. But in making the connection the pupil is in fact forging a unity between what had hitherto been regarded as disparate material. In the third example, the experience is clearly one of interaction through dialogue. But note that the educational experience here is not the mere swapping of ideas (still less is it 'brainstorming' which negates the very possibility of a unity). It is a conversation that builds on what has gone before so that the conclusion is reached through a cumulative effect. What is happening here is that the unity is actually forged by the participants themselves-even if the conclusion reached is inconclusive (rather like some of Plato's dialogues). It is not that the participants themselves have formed a unity (though this may be one of the beneficial side-effects of the dialogue) but that the dialogue, if successful, has enabled an integral experience of subject matter at the level of meaning to emerge. And again, rather as in the case of the other two examples, the role of the teacher or tutor must be low-key and never dominant.

\section{EDUCATIONAL EXPERIENCE AND SELF-FORMATION}

In this final section I wish to explore Gadamer's idea that certain kinds of experience can be integrated into a whole life. What is needed here is some idea of how this can be achieved from the agent's perspective. Charles Taylor has helped us considerably in providing a framework 
through the contrast of a strong and weak evaluator (see Taylor, 1985 passim, but especially Chapter 1 for an introduction to the concept of strong evaluation). Taylor explains that 'weak evaluation' is only concerned with the evaluation of the best means to attain pre-given ends (e.g. ends delivered through desires) whereas strong evaluation seeks to shape and modify existing ends. I am particularly interested in the role strong/weak evaluation plays in fashioning self-identity.

What would a weak evaluator look like in educational terms? It would surely be someone who viewed their education in an instrumental way in which the actual educational experiences were to be blotted out once the appropriate qualification had been obtained. Such a person may have been a good student but their experiences in learning are discounted in terms of their meaning for him or her. Perhaps the weak evaluator sees herself as a strict pragmatist and rather glories in what seems to her a rather fine destiny. Certainly, assessment-driven pedagogies do nothing to discourage such a perspective.

What would a strong evaluator look like? It would be someone who was trying to forge a self-identity in which educational experiences play a part, perhaps a major one, in a life. He would use these experiences to try and work out what kind of values were important in terms of his own motivation. Possibly it might be in terms of 'chemist' or 'historian' or 'engineer'; in this case identity would be fashioned through the disciplines. But stronger candidates for thinking about identity might be a continuum running from creativity and the practical through to the reflective: the agent may think of himself as 'creative', or 'practical', or perhaps 'intellectual'. What I am suggesting is that individual educational experiences take on a more influential role when adopted by a person trying to test a possible identity against experience or using an experience to strengthen an identity. This would mean that part of what a 'poor' or 'light' pedagogy involves is encouraging children and students to find and strengthen their identities as strong evaluators using educational experiences as a way of doing this.

Correspondence: Geoffrey Hinchliffe, Centre for Staff and Educational Development, University of East Anglia, Norwich NR4 7TJ, UK.

Email: g.hinchliffe@uea.ac.uk

\section{NOTES}

1. The following assumption, in a paper surveying assessment methods in Higher Education is typical: 'If you want to change student learning then change the methods of assessment' (Brown et al., 1997, p. 9). In this article I wish to suggest the priority of the quality of the learning experience.

2. For example, Paul Willis (1977) shows how 'having a laugh' at the teacher's expense, experienced by teenagers at a working class urban school helps to promote a certain independence and solidarity, quite independent of any curriculum aims.

3. Winston Churchill's encounter with education is a case in point. Here he is in reflecting on his early life, in his 50s-10 years before becoming Prime Minister: 
It was at the 'Little Lodge' I was first menaced with Education. The approach of a sinister figure described as 'the Governess' was announced. Her arrival was fixed for a certain day. In order to prepare for this day, Mrs Everest [his nanny] produced a book called Reading Without Tears. It certainly did not justify its title in my case. I was made aware that before the Governess arrived I must be able to read without tears. We toiled each day. My nurse pointed with a pen at the different letters. I thought it all very tiresome. Our preparations were by no means completed when the fateful hour struck and the Governess was due to arrive. I did what so many oppressed peoples have done in similar circumstances: I took to the woods (Churchill, 1930, p.11).

\section{Later on, Churchill summarises his Harrow experience thus:}

But this interlude of school makes a sombre grey patch upon the chart of my journey. It was an unending spell of worries that did not then seem petty, and of toil uncheered by fruition; a time of discomfort, restriction and purposeless monotony (p. 46).

\section{REFERENCES}

Brown, G., Bull, J. and Pendlebury, M. (1997) Assessing Student Learning in Higher Education (London, Routledge).

Churchill, W. S. (1930) My Early Life (London, Fontana Books).

Copeland, T. (1998) Constructing History: All Our Yesterdays, in: M. Littledyke and L. Huxford (eds) Teaching the Primary Curriculum for Constructive Learning (London, David Fulton Publishers), pp. 119-130.

Dewey, J. (1934) Art as Experience (New York, Minton, Balch and Company).

DfES (2004) Key Stage 3 National Strategy: Pedagogy and Practice, Unit 2: Teaching models.

English, A. (2009) Transformation and Education: The Voice of the Learner in Peters' Concept of Education, Journal of Philosophy of Education, 43.Supp. 1, pp. 75-95.

Gadamer, H.-G. (1975, revised 1989) Truth and Method (London, Sheed and Ward).

Grice, H. P. (1957) Meaning, Philosophical Review, 66.3, pp. 377-88.

Heidegger, M. (1977) Basic Writings (San Francisco, CA, Harper).

Masschelein, J. (2010) Educating the Gaze: The Idea of a Poor Pedagogy, Ethics and Education, 5.1, pp. 43-53.

Noddings, N. (1993) Excellence as a Guide to Educational Conversation, Teachers College Record, 94.4, pp. 730-743.

Oakeshott, M. (1975) On Human Conduct (Oxford, Clarendon Press).

Peters, R. S. (1966) Ethics and Education (London, George Allen and Unwin).

Selley, N. (1999) The Art of Constructivist Teaching in the Primary School (London, David Fulton Publishers).

Taylor, C. (1985) Philosophical Papers (Cambridge, Cambridge University Press).

Tubbs, N. (2005) The Philosophy of the Teacher, Journal of Philosophy of Education, 39.2 Special Issue.

Weil, S. (1977) Waiting on God (Routledge, Kegan and Paul).

Willis, P. E. (1977) Learning to Labour: How Working Class Kids Get Working Class Jobs (Farnborough, Saxon House).

Wittgenstein, L. (1958) Philosophical Investigations (Oxford, Blackwell). 
Copyright of Journal of Philosophy of Education is the property of Wiley-Blackwell and its content may not be copied or emailed to multiple sites or posted to a listserv without the copyright holder's express written permission. However, users may print, download, or email articles for individual use. 